\title{
Review
}

\section{A review of ecological interactions between crayfish and fish, indigenous and introduced}

\author{
J.D. Reynolds ${ }^{(1)}$ \\ Received January 17, 2011 \\ Revised March 14, 2011 \\ Accepted March 16, 2011
}

Key-words: crayfish, freshwater fish, keystone species, competition, predation, translocation, alien invasive species, native species

\section{ABSTRACT}

Crayfish (decapods) and fish are both long-lived large members of freshwater communities, often functioning as keystone species. This paper reviews interactions between these, with emphasis on the European context. Native crayfish and fish are in ecological balance, which may involve mutual predation, competition and sometimes habitat disturbance. This balance is disrupted by range extensions and translocations of native fish or crayfish into exotic situations. Some fish and crayfish have been translocated globally, chiefly from North America to other continents. Nonindigenous crayfish species (NICS) may impact on native fish, just as introduced fish impact on indigenous crayfish species (ICS). Competition between ICS and NICS may result in making the former susceptible to various mechanisms of interaction with fish, indigenous or introduced. In Europe, long-established NICS - signals, spiny-cheek and red swamp crayfish - may occur in greater densities than ICS; they are more tolerant and aggressive and show more interactions with fish. More recent introductions, still restricted in distribution, have not yet received enough study for their impacts to be assessed. Interactions between fish and crayfish in North and South America, Madagascar and Australasia are also explored. Mechanisms of interaction between fish and crayfish include mutual predation, competition for food and spatial resources, food-web alteration and habitat modification. Resultant changes in communities and ecosystems may be physical or biotal, and affect both ecosystem services and exploitation potential.

\section{RÉSUMÉ}

\section{Interactions écologiques entre les écrevisses et les poissons, indigènes et introduits}

\author{
Mots-clés : \\ écrevisses, \\ poissons \\ d'eau douce, \\ espèces clés, \\ compétition, \\ prédation,
}

Les écrevisses (décapodes) et les poissons appartiennent aux grandes communautés d'eau douce à longue durée de vie et fonctionnent souvent comme des espèces clés. Cet article synthétise la littérature sur les interactions entre poissons et écrevisses, en mettant l'accent sur le contexte européen. Les écrevisses et les poissons autochtones sont en équilibre écologique, ce qui peut impliquer la prédation mutuelle, la compétition et parfois la perturbation des habitats. Cet équilibre est perturbé par l'extension de leur distribution et les transferts de poissons indigènes ou d'écrevisses dans des situations exotiques. Certains poissons et écrevisses ont été transférés au niveau mondial, principalement de l'Amérique 
translocation, espèces

exotiques

invasives,

espèces

indigènes du Nord vers d'autres continents. Les espèces d'écrevisses non indigènes (NICS) peuvent avoir un impact sur les poissons indigènes, et inversement les poissons non indigènes sur les espèces d'écrevisses indigènes (ICS). La concurrence entre ICS et NICS peut se traduire par leur sensibilité à divers mécanismes d'interaction avec les poissons indigènes ou introduits. En Europe, les écrevisses non indigènes (NICS), établies de longue date (écrevisse signal, écrevisse américaine et écrevisse rouge de Louisiane), peuvent avoir des populations de plus grande densité que celles des écrevisses indigènes (ICS) ; elles sont plus tolérantes et agressives et montrent plus d'interactions avec les poissons. Les espèces introduites plus récemment, et encore limitées dans leur distribution, n'ont pas encore fait l'objet de suffisamment d'études pour pouvoir évaluer leurs impacts. Les interactions entre les poissons et les écrevisses en Amérique du Nord et du Sud, en Madagascar et en Australasie sont également analysées. Les mécanismes d'interaction entre les poissons et écrevisses comprennent la prédation mutuelle, la compétition pour la nourriture et les ressources spatiales ainsi que la modification du réseau trophique et de l'habitat. Les changements qui en résultent, en ce qui concerne les communautés et les écosystèmes, peuvent être physiques ou biotiques et affecter à la fois les services écosystémiques et le potentiel d'exploitation.

\section{INTRODUCTION}

Fish are often considered to control the structure of freshwater systems. However, decapods (crayfish and crabs), as the largest active predatory or broadly omnivorous invertebrates in many freshwater systems, are also capable of dominating secondary production and biomass (Geiger et al., 2005; Gherardi, 2007; Reynolds and Souty-Grosset, 2011). In Europe and North America crayfish have long been known to affect habitats and communities (e.g. Abrahamsson, 1966; Lorman and Magnuson, 1978; Momot et al., 1978). For example, in a range of North American ponds, crayfish had both direct and indirect community effects on the biomass of zooplankton and phytoplankton assemblages and peak levels of dissolved oxygen, also strong negative effects on macrophyte establishment, metaphyton abundance and composition, gastropod biomass, and the density of bullfrog tadpoles (Dorn and Wojdak, 2004). These and other studies suggest that lakes and ponds with abundant crayfish will be structurally comparatively simple, with few macrophytes and gastropods. In such systems some species of amphibians and fish will perform poorly, while other organisms may benefit (Dorn and Wojdak, 2004).

Freshwater decapods often coexist with fish in streams and lakes, although other situations where crayfish live, including swamps and temporary wetlands, may not support fish. Both decapods and fish may control community biodiversity through their large size, longevity and trophic specializations. They may also act as ecosystem engineers; they are thus keystone species. Size helps in dominance, while longevity means a long environmental memory, so intermittent or occasional adverse environmental situations can have long-lasting impacts on populations.

There are over 550 species of freshwater crayfish, widely distributed across the globe, chiefly in temperate and subtropical water bodies and wetlands. Freshwater crabs (over 1100 species, many restricted or endemic) occur predominantly in tropical streams and lakes and are rarely sympatric with crayfish, although Potamon spp. crabs overlap with white-clawed crayfish Austropotamobius pallipes in southern Europe (Barbaresi and Gherardi, 1997). However, the invasive diadromous mitten crab Eriocheir sinensis is increasingly entering the native ranges of several temperate crayfish species. Some crayfish have expanded their distributional ranges; others have been widely translocated beyond their normal range, such as the thin-clawed crayfish Astacus leptodactylus to western Europe (Souty-Grosset et al., 2006), and still others have been introduced to many land areas overseas, e.g. signal crayfish Pacifastacus leniusculus and red swamp crayfish Procambarus clarkii from North 
America to Europe, Africa and Asia (Holdich et al., 2009b). In their new locations, these nonindigenous crayfish species (NICS) must be distinguished from indigenous crayfish species (ICS).

The number of freshwater fish has been variously estimated between 9000 and 25000 species, with a median estimate of around 16000 species. Largely because of their commercial interest, many species of fish have been translocated or introduced around the globe, thus tilapias have been moved from Africa throughout the tropics, carps across Eurasia and northern hemisphere salmonids introduced to South America, South Africa, Tasmania and New Zealand. Within Eurasia, cyprinid and percoid fishes have been widely established outside their native ranges. All these moves have had major community consequences.

There has been an alarming decline in crayfish populations worldwide, recently documented by IUCN (see, for example, Edsman et al., 2010; Füreder et al., 2010). Many factors have been implicated in this decline, among them deteriorating aquatic environments, waterborne biocides and toxins, overfishing and disease. In addition, recent decades have seen an enormous expansion in global translocations of organisms, leading to novel ecological situations involving changed balances of competition and predation. Alien predatory fishes may negatively impact on native crayfish, while fish populations may be affected by predation and competition from various types of organisms, including exotic crayfish (Degerman et al., 2007).

Mechanisms of interactions between fish and crayfish may be direct, e.g. predation or competition, or indirect, through alteration of habitats and interactions with the ecosystem, such as through bird and mammal predators or through food-web manipulation leading to changed littoral communities. Competitive interactions have two main focuses, food and shelter. When both decapods and co-existing fishes are omnivorous there will be competition and mutual predation, depending on relative size and vulnerability. Reciprocal uses may reflect such trophic interactions; crayfish are often used as bait for sport fish, while fish carcasses may be used as bait for crayfish traps and crab pots. Decapods are particularly vulnerable as juveniles and while undergoing ecdysis, fishes particularly as eggs or 0+ juveniles. Fish as prey also have very high assimilation efficiency (llhéu and Bernardo, 1995). Depending on species, the predation balance may be more or less unequal, although historically, fish predation on crayfish has been most discussed and occurs wherever both species are present. For example, eels are widely considered inimical to crayfish.

These interactions may be complex, in part deriving from ontogenetic habitat shifts, documented for a wide variety of invertebrates and vertebrate species (Harrison et al., 2006). In freshwater fish and crayfish these probably result from individual decisions that minimize the risk of predation by larger conspecifics or by predatory fish, until a size is reached at which the risk of predation is low enough to be outweighed by the high foraging potential of the new habitat (Werner and Hall, 1988). North American stream-dwelling crayfish such as northern Clearwater crayfish Orconectes propinquus, phallic crayfish O. putnami, Appalachian brook crayfish Cambarus bartonii and signal crayfish Pacifastacus leniusculus all show ontogenetic shifts in spatial distributions (e.g. Harrison et al., 2006); juveniles are restricted to shallows with rocks for cover, minimizing predation by larger adults and predatory fish, and adults to deeper pools, minimizing vulnerability to terrestrial predators. In Europe juvenile white-clawed crayfish Austropotamobius pallipes species complex find refuge in marginal vegetation and debris, fine gravel and plant roots, while larger ones are in the stony bed (Demers et al., 2004). Fish may also change their behaviour or habitat preferences with age, juveniles typically avoiding preferred habitats of adult predators.

The main fish-crayfish interactions are summarized below:

Crayfish

Predate on fish eggs, juvenile fish

Compete for food, shelter

Alter habitat (ecosystem engineers)

Affect community resources, biodiversity

\section{Fish}

Predate on juvenile, adult crayfish

Compete for food, shelter

Inhibit foraging behaviour

Affect community resources, biodiversity 
A number of scientists have addressed the topic of fish and crayfish interactions over the years (e.g. Stein, 1977; Momot et al., 1978; Dorn and Mittelbach, 1999; Nyström, 2001, Ilhéu et al., 2007). This review therefore makes no claims to be exhaustive. It seeks to elucidate interactions of fish and crayfish, with particular emphasis on situations where one or both are exotic or expanding their ranges. The focus is on fish and crayfish in Europe, both indigenous and non-indigenous species. Crayfish/fish interactions are also explored in North America, Australia and elsewhere in the world, chiefly for the insights they may provide for the European situation.

\section{INTERACTIONS BETWEEN INDIGENOUS CRAYFISH SPECIES (ICS) AND FISH}

Where a freshwater community contains coexisting native crayfish and native fish, their interactions have evolved to be broadly in balance in the relevant habitats. Such a "balance" constitutes a fluctuating equilibrium in relation to changing stressors, not including current ongoing changes in climate. Some examples of coexistence between native decapods and fish are given below, principally from Europe and North America.

During recent glacial periods many European freshwater organisms, including percid and cyprinid fishes and crayfish, maintained their existence in southern European refugia, moving back through temporary periglacial lakes and swollen rivers to recolonize more northerly areas as the ice retreated (Grandjean et al., 2006). The crayfish/fish situation is different for each region, e.g. in the Mediterranean and Lusitanian regions where white-clawed crayfish Austropotamobius italicus coexist with indigenous cyprinids, or where the stone crayfish A. torrentium co-occurs with the Danube ichthyofauna in central and eastern Europe. The situations with regard to Baltic and Atlantic Europe fauna are reviewed here.

The Baltic region today has a diverse fish fauna compared to that of Atlantic Europe, including pike, percoids (perch, zander, bullhead), loaches, cyprinids and diadromous fish such as lampreys, eels, salmonids and sticklebacks. The native noble crayfish Astacus astacus, perch, pike and eels exemplify the balance between native keystone species. Appelberg et al. (1993) showed that fish presence tends to induce behavioural responses among noble crayfish, causing them to remain in shelters throughout the day. Divergent effects of crayfish on fish have been reported; these may be highly dependent on the species and methods used, and the effects of crayfish on fish populations deserve further study to better understand community processes in streams (Degerman et al., 2007).

In Scandinavia there is little evidence that native noble crayfish affect fish population densities in temperate stream communities (Stenroth and Nyström, 2003; Degerman et al., 2007). In a long-term study of electro-fishing results in natural streams, comparisons of stream fish densities between years with absence or presence of crayfish in different densities showed no effect of native crayfish on fish. Other studies have shown comparable results for crayfish and littoral fish in large oligotrophic lakes, the flexible feeding habits of the fish allowing them to coexist without demonstrable impacts.

Within their natural range noble crayfish face many threats, including habitat deterioration, pollution, various threats from alien crayfish and predation by eels and invasive mink (Paaver and Hurt, 2009). There is no field evidence that salmonid fish adversely affect noble crayfish; however when experimentally reared together, noble crayfish initially predated on Atlantic salmon parr, but their disturbance of sediments also made feed particles more available to salmon, which were eventually larger than in monoculture (Holm, 1989).

The natural situation may change when species are introduced, although introduced signal crayfish appear not to affect Scandinavian stream fishes (Degerman et al., 2007). Söderbäck (1994) studied interactions between perch (Perca fluviatilis L.) and juveniles of the indigenous noble crayfish when introduced signal crayfish were also present. Perch predated more on young of year noble crayfish than on signals, apparently because signals displace nobles from their refuges, exposing them to predation. There is thus asymmetric competition between 
native and introduced crayfish (Söderbäck, 1994). Pike are more serious predators of crayfish (Raat, 1988) because they take all sizes. Crayfish respond to chemical cues from predatory fish species (Appelberg et al., 1993). They may survive therefore where shelters are abundant, however no reciprocal impact of crayfish on stocks of these fish is known, though crayfish may consume pike and perch eggs.

In contrast to other fish, eels (Anguilla anguilla L.), plentiful in the region until their recent decline, are considered natural enemies of crayfish occupying similar habitats. In Nordic countries eels forage under stones in lakes and are considered a danger to crayfish survival (Svärdson, 1972). However, two morphs of European eels are now generally recognized, differentiated by head width; narrow-headed eels are most prevalent in enriched lakes while broad-headed eels are often predominant in oligotrophic streams. As broad-headed eels apparently do not occur in culture (e.g. Proman and Reynolds, 2000) it has been suggested that head shape is diet-related rather than innate. Broad-headed eels eat larger and tougher invertebrates, including crayfish, whereas narrow-headed eels feed on small and soft-bodied invertebrates such as water lice (Asellus aquaticus) (Moriarty, 1974).

In Atlantic Europe, the first indigenous freshwater fish were diadromous (e.g. salmonoids, eels, lampreys, stickleback), colonizing newly ice-free Atlantic lands from the surrounding seas. In contrast, crayfish are intolerant of salt water, and would have spread northward with some primary freshwater fish such as percoids and cyprinids. Perch, pike and cyprinids colonized Great Britain naturally after the glaciation, but like crayish must have been introduced by man to offshore islands. There is evidence that white-clawed crayfish have been in England since before 1500 (Holdich et al., 2009a) and probably also Ireland, and so under IUCN criteria (2010) are considered native in both islands.

Ireland is a more extreme example than Britain, having been isolated from Britain and mainland Europe for about 9000 years. Native Irish fish exhibit broad ecological niches, sometimes reduced by competition. Studies show much interaction between native and introduced fish pike progressively extinguished char (Salvelinus spp.) from many midland lakes (Went, 1971) and introduced perch competed with native trout in Poulaphouca reservoir, preventing them getting the full dietary range (Moriarty, 1963). Genetic evidence suggests that white-clawed crayfish Austropotamobius pallipes were introduced to Ireland, most probably in medieval times (Gouin et al., 2003; Reynolds, 2008). Crayfish today coexist in balance with a number of native and introduced fish. Crayfish predation by native diadromous eel (Moriarty, 1973; Reynolds, 1979) and trout (Kennedy and Fitzmaurice, 1971) is important, but not critical to the species, and evidently neither is predation by introduced fish, although the majority of pike and perch guts examined contained crayfish (Moriarty, 1963; Lucey and McGarrigle, 1987).

Competition between white-clawed crayfish and fish may be for shelter, over-wintering places or food. Crayfish in Irish lakes are chiefly inshore dwellers, up to $10 \mathrm{~m}$ deep, under stones or in Chara mats. White-clawed crayfish have been known to alter the Irish lake habitat by macrophyte reduction (Matthews and Reynolds, 1992; Matthews et al., 1993) and to modify the macroinvertebrate food web (Matthews et al., 1993). There is some reciprocal predation on juvenile stages; trout eat small crayfish, while white-clawed crayfish may eat salmonid eggs and alevins (Peay et al., 2009) and other small fish, including adult stickleback (Reynolds and O’Keeffe, 2005).

Native Irish lake salmonids may be open-water or inshore-dwelling, with different trout morphs specializing on pelagic or benthic habitats. Eels in such lakes chiefly live inshore, foraging for benthic invertebrates (including crayfish) under stones. Crayfish do not occur in the largest Irish lakes: this has been suggested by Moriarty (personal communication) as indication of predation by eels. However, while most large Irish lakes (e.g. Neagh, Erne, Corrib, Derg) contain large eel stocks, they are low in their river systems, so this may be a function of lake position rather than lake size. Eels grow slowly and may live for up to 60 years in Irish fresh waters (Moriarty, 1983; Poole and Reynolds, 1996). They occupy the same habitats as crayfish, but evidence for control of Atlantic crayfish by eels is not strong. 
North America has a much more diverse fish and crayfish fauna than Europe. In addition, some species are regularly translocated by man or are currently increasing their ranges and displacing others, so fish/crayfish interactions are correspondingly more complex. Lodge and Lorman (1987) noted reductions in submersed macrophyte biomass and species richness by the crayfish Orconectes rusticus; this is likely to affect survival of some fish.

There are a number of studies of interactions between native North American fish and crayfish, e.g. Lewis and Helms (1964) noted that crayfish were a preferred forage of largemouth bass Micropterus salmoides (Centrarchidae), native to the Mississippi basin and Great Lakes. Taub (1972) examined such exploitation of the crayfish Cambarus diogenes in an Ohio pond, while Englund (1999) showed that stream fish will influence native crayfish distribution in a Kentucky stream. Native fish may interact with native crayfish in several ways, including predation and competition for resources, directly or through altering habitats or food-webs, resulting in broad impacts on littoral communities. Carpenter (2005) showed that when Orconectes virilis was introduced to the Colorado River basin, native fish growth was reduced as a result of competition for food, but crayfish were not themselves affected. Kirk and Smock (2000) noted the effect of size on competitive outcomes for shelter between the crayfish Cambarus longulus and a megalopteran larva. However, when predatory bass were present, both prey species shared refuges. Sculpin and crayfish also co-occur in stony habitats, and their interactions have been much studied. $O$. virilis and slimy sculpin Cottus cognatus may compete for food (Miller et al., 1992), while crayfish may also affect the predator-prey relationships between sculpin and bass (McNeely et al., 1990). Finally, Keller and Moore (2000) looked at the impact of crayfish prey size on behaviour of a variety of other fish species.

In streams of north-central Mississippi fish predation is a plausible mechanism to explain both relatively low crayfish densities and differences in stream size occupied by various native crayfishes. In mesocosm experiments, Adams (2007) investigated effects of predatory channel catfish, Ictalurus punctatus on native cambarid crayfishes (primarily Procambarus hayi and Orconectes chickasawae). Catfish significantly reduced crayfish survival, although availability of shelter reduced catfish predation on smaller crayfish. Results suggested a reduction in mean crayfish growth in the presence of catfish, perhaps through restricting microhabitat use (Adams, 2007).

Competition may not necessarily occur. Bishop et al. (2008) looked unsuccessfully for evidence of interference competition for shelter between native banded sculpin Cottus carolinae and adult bigclaw crayfish Orconectes placidus. These co-occur naturally in high densities in deep stream pools of the Cumberland River Basin, Tennessee, often living under rocks separately or together and creating a potential for strong interactions over shared resources. In test enclosures in streams, each containing one rock shelter, both species shared the shelter rather than competing for it. Bishop et al. (2008) hypothesized that if predators were present in the pool habitats of this stream, stronger interactions could occur.

Rahel and Stein (1988) studied predator-prey interactions using a fish predator, smallmouth bass Micropterus dolomieui and two prey species, the johnny darter fish Etheostoma nigrum and rusty crayfish Orconectes rusticus. Darter activity and shelter-use were similar whether or not crayfish were present, but when predatory bass were introduced, darters sharply reduced their activity to just $6 \%$ of control rates and spent most of the time hiding under shelters. When both crayfish and bass were present, however, darter activity increased, because crayfish evicted them from shelters, increasing their vulnerability to bass predation. Conversely, bass increased the vulnerability of small fish to crayfish by forcing these fish to seek cover under shelters occupied by crayfish. Intimidation effects of bass on darters last for at least $24 \mathrm{~h}$ after the bass was removed, showing that predators can influence prey behaviour even after the predatory species are no longer present (Rahel and Stein, 1988).

In northern Wisconsin lakes introduced rusty crayfish $O$. rusticus are replacing both previously invading northern clearwater crayfish $O$. propinquus and native virile crayfish $O$. virilis. DiDonato and Lodge (1993) examined these relationships and found that small O. propinquus were more vulnerable to predation in the field than larger $O$. rusticus, since fish predators prefer small crayfish. Thus, O. rusticus can replace O. propinquus due to natural size differences. 
Experiments also suggested that fish predation and interspecific competition between crayfish interacted to drive the replacement of $O$. virilis by $O$. propinquus and the replacement of both by O. rusticus (DiDonato and Lodge, 1993). Garvey et al. (1994) also explored the role of fish predation interacting with competition to drive these changes in crayfish species composition in this dynamic system. When exposed to predatory largemouth bass Micropterus salmoides, native $O$. virilis were found to be more susceptible to fish predation than either of the invading crayfish species (Garvey et al., 1994). Although O. virilis grows larger than the invaders, it is innately less aggressive than them. Therefore, when shelters were limiting and fish present, $O$. virilis was excluded from shelters by crayfish invaders. Its risk to predation was increased by behaviour patterns such as increased activity and swimming. As a result bass consumed $O$. virilis at high rates and these might eventually be replaced in lakes.

The outcome of interference competition among the crayfish was modified by largemouth bass predation, while competitive interactions also influenced crayfish susceptibility to fish predation. $O$. virilis suffered high mortality to fish predation in the presence, rather than in the absence, of the two invading species. Thus, in sympatry where predators are selective and prey species compete, predation and competition interact to determine community structure (Garvey et al., 1994).

In another study, Dorn and Wojdak (2004) investigated the interactions of native and exotic crayfish with a large freshwater fish predator (sunfish, Lepomis sp.) in the context of community structure of shallow water habitats. In cage feeding trials, adults of the exotic rusty crayfish $O$. rusticus and the native $O$. virilis grazed at similar rates on Chara macroalgae. However, when direct interactions were possible between sunfish and crayfish, O. rusticus showed higher feeding rates than $O$. virilis. This result is consistent with differences in overall predation vulnerability of these species, and suggests that the effects of exotic crayfish might be different in the presence of predators. The results provide valuable empirical evidence of mechanisms of $O$. rusticus invasive spread, including the exclusion of other crayfish and competition for space.

Minor differences between species may favour differential predation. Dorn and Trexler (2007) studied two co-existing species of crayfish (Procambarus alleni and $P$. fallax) native to a subtropical flowing slough in southern Florida. In laboratory and mesocosm experiments they also compared life history traits and performance of the respective species to explain dominance shifts in the local crayfish assemblages. Over the 9-year field study $P$. alleni densities were greatest in shallower, shorter-hydroperiod areas bordering the slough, while $P$. fallax densities were higher in deeper, longer-hydroperiod central areas, although there are no apparent barriers to movement. Density of $P$. fallax was not strongly affected by hydrological variation, but $P$. alleni density increased with more severe drought conditions, colonizing areas in the centre of the slough where they had been absent or scarce in wetter years. In experiments $P$. alleni survived drought conditions better, had higher growth rates, and was the dominant competitor for space and food (Dorn and Trexler, 2007). While drought probably limits $P$. fallax in the drier slough habitats, neither drought sensitivity nor interspecific competition with $P$. fallax can explain decreases of $P$. alleni with wetter conditions.

The results indicated that crayfish compositional dynamics in this wetland can not be explained by a competition-colonization tradeoff, because $P$. alleni is both the best competitor and the best at surviving in and colonizing areas with the strongest droughts. There is potential for selective effects of predators that co-vary with hydrology. In permanent lakes and streams containing fish, dominant crayfish show life history traits (large size, fast growth, competitive dominance) like those exhibited by $P$. alleni, which is absent from long-hydroperiod wetlands. While these traits make crayfish less vulnerable to predatory fish, Dorn and Trexler (2007) note that life-history models of community structure across gradients in permanence suggest the opposite traits should be favoured for co-existence with fish.

Crayfish can thus have a number of different relationships with fish, and interactions are not limited to the traditional ideas of fish as predators and crayfish as prey. Other interactions have been less well studied, and one potentially important interaction is the effect of crayfish as predators of fish eggs. Both pumpkinseed (Lepomis gibbosus) and bluegill sunfish 
(L. macrochirus) nest in shallow littoral habitats of lakes and ponds, and nests are guarded by the adult males. In experiments, Orconectes species crayfish infiltrated nests of both $L$. gibbosus and L. macrochirus, ate the eggs and had negative impacts on reproductive success of the sunfish, stopping reproduction completely in the case of bluegill sunfish (Dorn and Wojdak, 2004).

\section{IMPACTS OF EXOTIC FISH INTRODUCTIONS ON ICS AND NICS}

Freshwater fish have been introduced into all continents where crayfish are native, for example, sunfish from North America to Europe, brown trout and rainbow trout from Europe and north America respectively to South America and New Zealand and cichlids such as tilapias from Africa to south-eastern Asia and Australia. There have also been numerous translocations within continents. Zander (pikeperch) was spread westwards through Germany and France and introduced from continental Europe to Great Britain, while pike and perch are late mediaeval introductions from Great Britain to Ireland. All eat crayfish, though as shown above pike and perch do not have any measurable impacts on stocks. The regional impact of translocated fish on native crayfish stocks needs further study, and it remains difficult to predict the degree to which exotic crayfish will affect native ecosystems. Evidence in this section is drawn chiefly from examples from North and South America and Australia-New Zealand.

In North America the cooler-water Orconectes and Cambarus species have been much studied. In the southwestern United States crayfish dominate some streams but maintain low densities in others nearby. Many of these streams have complex fish faunas comprised of both native and exotic fish, some of which have overlapping home ranges with crayfish. Among the most widely dispersed of North American fishes are the sunfishes (Centrarchidae), of which several species are now widespread across temperate regions of the world. Smallmouth and largemouth bass (Micropterus spp.) compete successfully with native fishes, feeding on their young and on crustaceans, while male sunfish make substrate nests and guard eggs and young, ensuring good survival rates. Smallmouth bass prefer unvegetated coarse substrates, logs and boulders to macrophyte beds, fine silt or sand (e.g. Rankin, 1986; Brown, 2010), habitats also frequented by crayfish. Invasive signal crayfish in Nevada and California also preferred coarse substrates over fine (Abrahamsson and Goldman, 1970). This is apparently related to the strong anti-predator response and increased refuge use by signal crayfish when encountering fish predators (Söderbäck, 1994).

In Europe, as elsewhere, exotic predatory fish have had a large impact on native fish. In a small lake, resident planktivores rudd, roach and small perch were all affected by the introduction of pike-perch, a more effective predator than resident pike and large perch (Hölker et al., 2007). Two species (roach and small perch) adapted their behaviour and reduced activity; roach also showed a shift in habitat. These fish survived in the face of the new predator, whereas rudd, which did not adapt, declined by more than $80 \%$ (Hölker et al., 2007). Similarly, fish predators induce a behavioural response in cohabiting crayfish, or they suffer drastic declines.

Southern hemisphere native fish faunas are usually dominated by galaxiids. They are often diadromous, with marine juvenile stages, like Galaxias maculatus which has a disjunct distribution in South America, South Africa, New Zealand and Australia. Native parastacid crayfish occur in all southern continents except Africa. Shelter is important to southern hemisphere freshwater crayfish, both in the wild and in culture (Wangpen, 2007).

Australia has over 200 indigenous freshwater fish species, but these show relatively little evidence of specialization and are vulnerable to the widespread introductions of fish such as carp, tilapias and mosquitofish (Morgan et al., 2004; Olden et al., 2008). Yabbies Cherax albidus coexist with a suite of native predatory fishes in both temporary and permanent Australian waters, whereas the marron C. tenuimanus of Western Australia, although occupying perennial rivers, has few native fish predators. In Australia galaxiids are apparently in balance with native crayfish despite interactions, although some, including jollytail Galaxias maculatus, will eat small yabbies. However, introduced fish have sometimes strongly affected both native fish and crayfish in Australia, New Zealand and South America. 
Brown trout, rainbow and brook trout were all introduced to Australia and Tasmania, where they feed on invertebrates, including crayfish. Many New Zealand streams shelter both native crayfish Paranephrops planifrons and native galaxiid fishes, as well as introduced trout, but abundances of crayfish and galaxiids are significantly lower in streams with trout. In streams without trout, substrate size is one of the most important factors determining crayfish abundance, although water chemistry and other factors may also be at play. Simon and Townsend (2003) looked at impacts of salmonid invaders on New Zealand stream ecosystems. Whereas native galaxiids use mechanical cues and feed both day and night, brown trout are strong visual predators. Native crayfish are negatively correlated with brown trout presence (Usio and Townsend, 2000; Whitmore et al., 2000). This may be because native crayfish respond to chemical cues from native opredatory fish, but not from introduced trout (Shave et al., 1994). However, other macroinvertebrates may be more negatively affected by acidification than by trout.

Olsson et al. (2006) investigated the influence of introduced brown trout (Salmo trutta) on the distribution of native crayfish, native galaxiid fishes and invertebrate fauna in New Zealand streams with and without trout. Macroinvertebrates other than crayfish were more abundant and diverse in trout streams than in streams without trout. Gut content analysis of trout and native fish showed an overlap in diet (mostly invertebrates). Crayfish, however, had a more omnivorous diet where detritus was the most frequently occurring food material. Macroinvertebrate abundance was related to environmental factors such as $\mathrm{pH}$, substrate, depth and total nitrogen. Differences in chemical characteristics also separated the streams with and without trout. While crayfish and galaxiids were present in streams with $\mathrm{pH}$ ranging from 7.9 down to 4.1, trout were absent from streams with $\mathrm{pH}$ less than 6.0. Such streams with $\mathrm{pH}<6.0$ may thus function as trout-free refuges. By protecting naturally acidic, brown water streams, New Zealand crayfish and galaxiid fish populations can be conserved within geographic areas where trout are present (Olsson et al., 2006).

Similarly, in southern South America, introduced trout are now the dominant predator in many streams. Soto et al. (2006) looked at the present distribution of introduced salmonids in large lakes and streams of southern Chile, and their potential effects on native fish faunas. Overall, introduced brown trout Salmo trutta and rainbow trout Oncorhynchus mykiss accounted for more than $60 \%$ of total fish abundance and more than $80 \%$ of total biomass. Brown trout were widely distributed, while rainbow trout were more restricted to the Andean streams with higher water discharge. Some $40 \%$ of the streams sampled did not have native fish. Native fish (chiefly galaxiids and atherinids) were more abundant in lakes than in streams but the highest native fish biodiversity occurred in streams of the central valley (Soto et al., 2006). Streams with higher conductivity, larger pool areas, more fine sediments, and low brown trout densities - usually catchments with higher anthropogenic disturbance - were more suitable as refuges for native fish. The comparison with acid New Zealand streams as refugia for native fish and crayfish is striking. Given this descriptive study we can only presume the negative impacts of trout and salmon on native fish, yet negative effects are very likely.

While most crayfish are found in temperate waters, there are seven endemic Astacoides crayfish species and 175 freshwater fish species in the tropical island of Madagascar, of which about $80 \%$ are indigenous. Their detailed ecology has been little studied and while native eels are believed to feed on crayfish no detail is available on fish interactions with crayfish. However, the blotched snakehead Channa maculata, recently introduced to Madagascar from Thailand and now invasive, is known to feed on juvenile crayfish and may pose a threat particularly to Astacoides betsiloensis (Jones, 2007).

\section{IMPACTS OF NON-INDIGENOUS CRAYFISH INTRODUCTIONS ON NATIVE AND EXOTIC FISH}

Because of the worldwide introduction and spread of exotic crayfish (e.g. Hobbs et al., 1989), their interactions with the freshwater community, particularly with fish, currently command 
much interest. Following a general discussion, separate case studies deal with three North American species - signals, red swamp and spiny-cheek crayfish - now widespread in Europe and elsewhere.

There is a long practice of discarding live crayfish surplus to use as fishing bait, which has led to many range expansions within North America (DiStefano et al., 2009). In Europe, buckets of live crayfish are used, often illegally, to establish new stocks. By whatever means Orconectes virilis has recently been found, among a number of other invasive species, in the Columbia River basin (Larsen et al., 2010). The accumulation of invasive species, including exotic crayfish, has been identified as a threat to the salmonid runs in this system. While ecological and economic impacts of O.virilis are relatively poorly known (Hobbs et al., 1989; McCarthy et al., 2006) the indigenous signal crayfish Pacifastacus leniusculus was infrequently found where the alien species occurs.

Where signal crayfish invaded a California stream, native sculpin (Cottus beldingi) showed reduced growth rates and gut fullness (Light, 2005). Both species are nocturnal, with most activity at dusk and by night. In a stream tank, observations on potential behavioral mechanisms of competition between the two species found that when crayfish were present sculpin reduced their use of refuges and pools, shifted into higher-velocity microhabitats, and spent more time fleeing. These behavioral shifts appear to be partly responsible for their reduced growth rates in the presence of crayfish (Light, 2005). Invasive signal crayfish also show increased refuge use when encountering fish predators (Söderbäck, 1994). By displacing sculpin from refuges and pools and increasing their activity rate, crayfish may increase the likelihood of predation on sculpin.

The impact of non-indigenous crayfish species (NICS) introductions on native crayfish is perhaps most felt and studied in Europe where both state-sponsored and more informal introductions of signal crayfish have occurred. Wherever NICS have been introduced to Europe from North America in the past two centuries, adverse effects have been experienced and ICS have declined or become eradicated (Souty-Grosset et al., 2006; Holdich et al., 2009b). The impact on native fish communities, however, has been less acutely scrutinized.

Holdich et al. (2009b) divided introduced crayfish into Old and New NICS (introduced preand post-1975 respectively). Old NICS such as spiny-cheek crayfish Orconectes limosus, signals Pacifastacus leniusculus and red swamp crayfish Procambarus clarkii are now generally widespread across many European countries, and the last is now distributed practically worldwide. These crayfish reach higher abundances than ICS so they are more attractive as a food resource. Some are also more fearless and aggressive, leading to more interactions with fish. Signal crayfish, having been officially introduced to Sweden and UK in order to boost crayfish crops, have received most study. For example, predation by European eels and perch on exotic crayfish has been studied by Blake and Hart (1993, 1995). Relatively rather less is known about interactions of fish with spiny-cheek or red swamp crayfish.

The development of large populations of $P$. leniusculus and $P$. clarkii in France raised questions of their relationships with fish particularly as a potential food resource for a range of European fishes, especially with carnivorous species such as pike Esox lucius, perch Perca fluviatilis and zander or pike-perch Stizostedion lucioperca (Neveu, 2001a, 2001b). Neveu (2001a) studied interactions between these species in experimental conditions. In a pond, pike decimated the population of $P$. leniusculus summerlings (age 1). The few crayfish surviving showed reduced growth and possibly delayed sexual maturity. Young of year (age 0+) perch had a mouth gape too small to affect $0+$ signals survival in their first summer, but older perch (age 1) will reduce crayfish $0+$ density. Crayfish growth rate was reduced merely by the sight of perch, even when excluded by a net. Zander summerlings (age 1) did not affect the survival rate of Pacifastacus YOY, but 2 years old zander reduced both their survival and growth (Neveu, 2001a).

These experimental results, and work in ponds with eels reviewed above, indicate that carnivorous fishes can reduce wild stocks of alien crayfish. Observations show the pike as the most effective predator regardless of size, while predation effectiveness in perch and zander require a sufficient difference in size between fish and crayfish. 


\section{THREE CASE STUDIES OF AMERICAN CRAYFISH ESTABLISHED IN EUROPE}

\section{> SIGNAL CRAYFISH PACIFASTACUS LENIUSCULUS}

Signal crayfish are today more abundant than native crayfish in much of Europe, including UK, Spain and southern Scandinavia. The range of environmental impacts of signal crayfish has been reviewed by Everard et al. (2009).

While impacts on fish have not been seen in Sweden (Söderbäck, 1994), signals have been shown to be deleterious to salmonids in UK (Peay et al., 2009). In Britain, since their introduction in the late 1970s, signal crayfish have become increasingly widespread in rivers, causing negative impacts on communities of aquatic plants, invertebrates and benthic fish. Game angling interests are concerned about possible impacts of signal crayfish on salmonids such as grayling Thymallus thymallus, brown trout or sea trout Salmo trutta and Atlantic salmon S. salar.

In addition to being a vector of crayfish plague, signal crayfish can impact adversely on the aquatic environment due to their relatively more rapid growth rates, burrowing activities and high ultimate population density (Guan and Wiles, 1997). In its native environment, recorded densities of $P$. leniusculus are under one adult per square $m$ (e.g. Abrahamsson and Goldman, 1970) but may be many times higher where it is invasive in Europe (Guan and Wiles, 1996; Nyström, 2001). Other invasive NICS in Europe reach similarly high densities. Bank erosion through burrowing activity of $P$. leniusculus (Stancliffe-Vaughan, 2009) and their impacts on the resident biota is such that in some cases it may be preventing water bodies in parts of England from attaining good ecological status, as prescribed under the Water Framework Directive (Holdich et al., 2009b).

High populations and activity of signal crayfish may have negative impacts on resident fish. Signals directly predate on small fish such as stone loach and bullhead (Guan and Wiles, 1997), and on fish fry (Rubin and Svensson, 1993), while alteration of invertebrate communities (Crawford et al., 2006) and cropping of macrophytes by crayfish may put themselves and other denizens at risk (Lodge and Lorman, 1987; Blake and Hart, 1993, 1995; Matthews et al., 1993; Nyström and Strand, 1995).

Studies have shown that predatory fish interfere with crayfish survival, activity and food consumption, e.g. perch strongly reduced crayfish activity and growth (Appelberg and Odelström, 1988). Blake and Hart (1995) looked in laboratory experiments at the vulnerability of juvenile signal crayfish to predation by European eel Anguilla anguilla and European perch Perca fluviatilis with different foraging behaviours. Both eels and perch elicited similar evasive behaviour when approaching and attacking crayfish; perch in open water and eels when foraging under stones. Crayfish usually escaped initial attacks but perch chased and caught more crayfish than did eels. Final survival rates of $P$. leniusculus were similar with both eel and perch predation (Blake and Hart, 1995).

Perch predate more on noble crayfish than on signals because of their lower effectiveness in competing for refuges (Söderbäck, 1994). Both species showed strong anti-predator responses to perch by increasing refuge use, but displaced $A$. astacus individuals become more exposed to the predator. This indirect effect of interactions among the two crayfish species and the predator may be important in the in situ replacement of $A$. astacus by $P$. leniusculus. Further, since signals chiefly hide under stones, they displace not only native crayfish but small fish sharing this habitat, such as salmon parr Salmo salar, bullhead Cottus gobio and stone loach Barbatula barbatula. By depriving the displaced fish of shelter they increase their susceptibility to predation, with potentially deleterious effects (Rahel and Stein, 1988; Guan and Wiles, 1997; Griffiths et al., 2004; Bubb et al., 2009).

Competition for winter shelter has been experimentally demonstrated among exotic signal crayfish and native juvenile Atlantic salmon (Griffiths et al., 2004). In winter both species are nocturnally active, but their capacity to share shelters with one another by day is known to be very low. At high densities there were significantly fewer Atlantic salmon sheltering 
when signal crayfish were present, whereas the proportion of signal crayfish sheltering was independent of the presence of Atlantic salmon. Juvenile Atlantic salmon out of shelter during the day in winter are believed to be very vulnerable to predators, therefore competition from crayfish for winter shelters may be detrimental to Atlantic salmon populations.

In a limestone headwater stream in Yorkshire, England, where signal crayfish are progressively replacing white-clawed crayfish, sites with white-clawed crayfish at normal densities (CPUE of 1-2 crayfish per trap night) had abundant juvenile trout, up to 100 per square $\mathrm{m}$ (Peay et al., 2009). However, surveys showed a significant negative relationship between resident trout and signal crayfish. Signals reached higher abundances (4-8 crayfish/trap night) and those sites had fewer fish (less than 20 per $\mathrm{m}^{2}$ ). Such reduction of salmonid recruitment in the presence of signal crayfish indicates the potential for significant impacts on important recreational trout fisheries.

\section{$>$ RED SWAMP CRAYFISH PROCAMBARUS CLARKII}

The red swamp crayfish Procambarus clarkii, indigenous to south-eastern United States, now supports extensive aquaculture in ponds and ricefields there and in many parts of the world (Huner and Avault, 1979). Red swamp crayfish are spreading in shallow warm lagoons and fishponds across Europe, where their rapid population expansion now supports several commercial fisheries. Crayfish and fish seem in balance in American wetland systems, but $P$. clarkii has very marked negative impacts on exotic communities in Europe and elsewhere.

Unlike Pacifastacus leniusculus (above), which was reduced by fish predation (particularly pike), a pond population of $P$. clarkii maintained a stable population over a three years study despite the presence of numerous predators (pike and perch), with an estimated annual consumption by pike greater than the summer biomass of crayfish adults and a removal of the same biomass of crayfish adults by annual trapping (Neveu, 2001a). In mesocosms pike from $16 \mathrm{~cm}$ length eat red swamp crayfish throughout the year even if forage fish are present. The level of predation is correlated to temperature. Maximum size of ingested crayfish is related to pike size; large pike over $40 \mathrm{~cm}$ length can swallow even crayfish adults above $8 \mathrm{~cm}$. In pond enclosures young pike eat $0+$ crayfish during their first summer. Protection by shelters is inefficient. In natural ponds the same is seen, even in the presence of macrophytes as refuges (Neveu, 2001a). P. clarkii stock stability must therefore be correlated to its high productivity and fast biomass turnover in this short-lived species.

$P$. clarkii is now a valued additional food resource for introduced pike in Spain (Elvira et al., 1996). In the Doñana and Guadalquivir marshes $P$. clarkii is the main food of two introduced fish species, pike Esox lucius and largemouth bass Micropterus salmoides (Guttiérrez-Yurrita and Montes, 1999) and of native eels, which formerly concentrated on carp Cyprinus carpio and on the introduced mosquito fish Gambusia affinis. Ramalho and Anastacio (2011) showed that the invasive bass quickly learnt to capture a new prey item, P. clarkii. Prey switching between red swamp crayfish and mosquito fish was also demonstrated, the bass selecting the most abundant item. Red swamp crayfish also feed on bass eggs in their nests, and it is likely that they also feed on pike eggs, which are large and adhere to vegetation. Invasive $P$. clarkii are also important predators of fish in temporary Mediterranean streams (llhéu et al., 2007).

Westman (1991) suggested that eels could be safely used to control exotic crayfish because they do not breed in freshwater and they may be able to enter crayfish hiding places. While some authors believe that fish predators have no possibility of eradicating an established exotic crayfish population and little chance of reducing it, eels introduced into the Rumensee, a small artificial impoundment in Switzerland, substantially reduced an expanding Procambarus clarkii population to less than $10 \%$ within three years, whereas pike, introduced at the same time had no obvious effect (Frütiger and Müller, 2002). These authors concluded that the effect of predatory fish is highest if shelter is sparse. Recently, laboratory and field experiments with European eel as potential controllers for invasive crayfish $P$. clarkii in Italy found that eels ambushed small and soft-shell crayfish from behind, and the presence of eels indirectly reduced crayfish trophic activity (Aquiloni et al., 2010). 
Elsewhere in its introduced range worldwide, the impact of $P$. clarkii on tilapia and other fish in Lake Naivasha has long been recognised (e.g. Lowery and Mendes, 1977; Hickley et al., 1994; Foster and Harper, 2006), while in the Nile this species interferes with the tilapia fishery by eating eggs of nest-spawning species (Holdich, 1999). Matsuzaki et al. (2009) compared the impacts of two introduced species, red swamp crayfish and common carp, as ecosystem engineers invading warm shallow lakes. Macrophytes responded differently to each invader. The ecosystems were modified in part through effects such as bioturbation, excretion, consumption and non-consumptive destruction.

\section{> SPINY-CHEEK CRAYFISH ORCONECTES LIMOSUS}

In North America Orconectes species are known to predate on salmonid eggs and juvenile fish. The genus has shown recent distributional changes, particularly in invasive $O$. rusticus and O. virilis (Swecker et al., 2010), which are likely to yield new evidence of community interactions. In its natural territory of Maine and Virginia the spiny-cheek crayfish Orconectes limosus is competitively inferior to expanding, invasive $O$. virilis, and it appears to have been widely extirpated (Swecker et al., 2010). However, O. limosus is a highly successful invader in Europe. Spiny-cheek crayfish were the earliest exotic crayfish introduced into Europe, and the first to bring in crayfish fungal plague, and are now widespread in lower quality habitats, chiefly deep rivers (Souty-Grosset et al., 2006). O. limosus is more active by day than are native astacids, and fecundity is also higher, with shorter development times (Kozák et al., 2006).

Haertel-Borer et al. (2005) studied the impact of O. limosus on European lake communities. At an average biomass of $32.2 \mathrm{~kg}$ per ha and littoral density of 2200 per ha, O. limosus accounted for almost half of the lake's invertebrate biomass. It comprised $15 \%$ of the annual consumption of pike and $48 \%$ of perch, and was important for the lake's littoral food web, perhaps also subsidizing the pelagial food web. O. limosus may have a negative impact on juvenile burbot (Lota lota) in Lake Constance (Hirsch and Fischer, 2008). However, negative impacts of $O$. limosus on fish are generally understudied.

\section{NEW NICS AND OTHER DECAPODS}

The list of crayfish species recently introduced into Europe (New NICS of Holdich et al., 2009b) currently includes five North American species - Procambarus sp. (the parthogenetic marmorkrebs), Orconectes immunis, O. virilis, O. rusticus and O. juvenilis, and two Australian species, Cherax destructor and C. quadricarinatus (Holdich et al., 2009b). Their spread is predicted, and the pattern of alien invasive crayfish distribution in Europe is clearly not yet stable. The ecology of New NICS has been little studied so far in Europe and the range of interactions with sympatric fish species is as yet unknown. Some, e.g. Orconectes species, are likely to have comparable impacts to those described in their North American communities (e.g. Mather and Stein, 1993). O. virilis may affect fish populations through competition for food, predation on eggs, and alteration of habitats via consumption of macrophyte beds (Larsen et al., 2010). O. virilis is known to eat fish eggs in N. America (Savino and Miller, 1991), while in the Upper Susquehanna River, New York, exotic O. rusticus is less vulnerable to predation by smallmouth bass than are the native $O$. propinquus and $O$. obscurus because bass were seeking smaller crayfish (Kuhlmann et al., 2008). O. rusticus has recently been detected in the Columbia River System, until now considered relatively unimpacted by invasive crayfish, and is believed to be widespread (Larsen et al., 2010). At sites where it was found, often at high densities, the indigenous Pacifastacus leniusculus was infrequently encountered. Clearly this interaction needs further study, but may provide an insight into possible interactions between these species, both now invasive in Europe.

Fish predators in North America frequently cause shifts in the abundance, behaviour and habitat use of their crustacean prey, and some of these fish have been introduced to Europe. 
In lake experiments Mather and Stein (1993) found that wherever smallmouth bass and rock bass Ambloplites rupestris densities were high, crayfish Orconectes spp. densities were consistently low. However, in some other lakes the density of introduced smallmouth bass was correlated with native signal crayfish density. Stein and Magnuson (1976) demonstrated a preference by crayfish Orconectes propinquus for pebbles over sand substrates in the presence of smallmouth bass. Further, $O$. propinquus densities on sand were inversely related to smallmouth bass densities, while foraging smallmouth bass were less inclined to select O. propinquus from larger, more structurally complex substrate types compared to simpler ones (Stein, 1977). This pattern differs somewhat from those from controlled field experiments in freshwater streams. For example, Dahl (1998) found that direct predation by the sculpin Cottus gobio significantly reduced the density of lotic signal crayfish in Sweden. Elsewhere, densities of crayfish were high where fish predators were sparse, especially given the spatial and temporal overlap between introduced smallmouth bass and native signal.

There is a negative correlation between the density of lake signal crayfish and submersed vegetation, consistent with the findings of Daniels (1980) in California, whereas the significant positive correlation with depth is similar to that reported by Abrahamsson and Goldman (1970). The latter hypothesized that lower signal crayfish densities in the shallows $(<10 \mathrm{~m})$ of Lake Tahoe were a result of light avoidance, strong wave action and predation.

An invasive decapod likely to become important in Europe in the future is the exotic mitten crab, Eriocheir sinensis, native to east Asia. Mitten crabs are omnivores, their juveniles eating mostly algae and detritus, but increasingly preying upon small invertebrates as they grow. In San Francisco Bay E. sinensis prey on freshwater shrimp, and there are concerns that mitten crabs can feed on the endangered Californian freshwater shrimp Syncaris pacifica where these two species overlap (Dittel and Epifanio, 2009). Known fish predators on mitten crabs in the Bay area include white sturgeon and striped bass, and probably also largemouth bass and larger sunfishes. Whether fish predation on mitten crabs will protect or further expose native crayfish remains to be investigated.

Mitten crabs also interact with crayfish where they overlap, as in the San Francisco Bay area with the introduced red swamp crayfish Procambarus clarkii in the south, and the introduced signal crayfish Pacifastacus leniusculus further north. Dittel and Epifanio (2009) note that mitten crabs are generally better competitors for space than are either species of crayfish. Negative interactions between mitten crabs and red swamp crayfish have been observed in the field, while laboratory investigations indicate that aggressive behaviour of crabs toward crayfish is significantly reduced in situations where shelter is not limited (Rudnick et al., 2003). In the Bay delta mitten crabs may reduce abundance and growth rates of the introduced signal crayfish, which supports a commercial fishery. In these oligohaline waters of San Francisco Bay, mitten crabs thus have the potential to reduce crayfish populations through aggressive behaviour and competition for shelter (Veldhuizen and Stanish, 1999).

\section{CONCLUSIONS}

Fish species interacting with crayfish are chiefly littoral. Over time, a balance between fish and crayfish has generally been achieved; however, stable distributions of indigenous crayfish and fish are becoming increasingly infrequent. The dominant mechanisms in fish-crayfish interactions are predation and competition for shelter or food. There is good evidence for fish predation chiefly on smaller crayfish, while crayfish, even generalists or detritus feeders, may predate on fish eggs or juveniles. There are also effects on littoral communities and other interactions with habitat and community, ultimately affecting biodiversity. Exotic crayfish may have a stronger impact on native fish, particularly salmonids, because of their superior competitiveness for shelter and their higher densities achieved.

In Europe it was long known that eels burrow among stones for their invertebrate food, including small crayfish, but we now know that perch, trout and especially pike are also serious predators on crayfish. Nonetheless, these fish may coexist with crayfish, even if the competition is unequal. Today, the situation in Europe has become both more complex and more fluid, 
with at least 11 non-indigenous crayfish species gradually ousting native crayfish, and scores of exotic fish introductions, again many of them invasive. The introduced species have widely varying life-histories and ecological influences and the resultant blend of native and exotic species is not yet finalized. Many of the interactions between fish and crayfish are consistent with optimal foraging theory (see for example Pyke, 1984). These include risk aversion and risk proneness, optimal patch foraging and optimal diets. Invasive fish or crayfish typically dominate in novel encounters with native faunal elements, which may result in extermination over time. Such processes leading to biotic homogenization, regional or global, have become a lively area of investigation and discussion (e.g. Olden, 2006).

Introduced crayfish generally reach greater densities than do native species and may supplant them, either through competition or plague transmission. Introduced or escaping organisms will alter natural ecosystems by various means, including enhancing predation opportunities. Thus, fishing for pike, perch and some other fishes may be improved by the presence of nonindigenous crayfish species (NICS) as supplementary food. Where either fish or decapods are farmed or exploited, their escape, as has happened widely, will inevitably lead to changes in natural communities and ecosystems, and will particularly affect native stocks. Many freshwater fish known to impact freshwater crayfish stocks have been brought into cultivation, and escapes are inevitable.

If NICS populations dominate natural systems and are then exploited, what are the implications? Faster growing, larger and/or more aggressive crayfish species are predicted to dominate permanent waterbodies. Dorn and Trexler's (2007) study tested this prediction using a dataset for two species of crayfish in southern Florida sloughs. The dominant competitor survived droughts best, and had traits matching those of dominant crayfish in permanent waters containing fish, including lower vulnerability to fish.

Today's widespread indigenous crayfish species in Europe have also undergone translocations in the past, as, for example, Astacus leptodactylus and Austropotamobius pallipes (Grandjean et al., 2001, 2006; Holdich et al., 2009b). Several North American crayfish species have also expanded their regional home distribution through outcompeting other crayfish or through human means, thus, Orconectes virilis may be displaced by O. rusticus and O. propinquus, which are more successful in competing for space (Garvey et al., 1994). A number of fish species, particularly carp and sunfish, have also been widely translocated. Such movements presumably resulted in shifts and adjustments in ecological systems, though regional translocations or range shifts of fish and/or crayfish may have less strong impacts on native species than those resulting from invaders from another continent. But where two invasive crayfish, $P$. leniusculus and $P$. clarkii, meet in Europe, laboratory experiments indicate that $P$. clarkii is quicker to take over and hold shelter (Alonso and Martínez, 2006), presumably with correspondingly greater protection from predatory fish.

However, the ecological outcome is not always predictable. Part of the complexity derives from ontogenetic habitat shifts, documented for a wide variety of invertebrates and vertebrate species (Harrison et al., 2006). Many stream-dwelling crayfish show ontogenetic shifts in spatial distributions; juveniles are restricted to shallows with rock or detritus cover, minimizing predation by larger adults and predatory fish, while adults are restricted to deeper pools minimizing vulnerability to terrestrial predators. In freshwater fish and crayfish these probably result from individual decisions that minimize the risk of predation by larger conspecifics or by predatory fish, until a size is reached at which the risk of predation is low enough to be outweighed by the high foraging potential of the new habitat (Werner and Hall, 1988).

There are still gaps in our knowledge of the interactions between fish and crayfish, both regionally and in detail. For example, there is little published information on behaviour or ecology of most east Asian indigenous crayfish. In Madagascar very little is known about interactions between tropical crabs and crayfish, and between decapods and fish, both indigenous and introduced. Finally, behaviours other than competition for space and food may await discovery. For instance, decapods have been implicated in kleptoparasitism or resourcestealing, which is little studied in freshwater communities. Six of the endemic tilapiine cichlids of Lake Barombi Mbo, Cameroon, steal the food of African freshwater crabs Potamon 
africanus (Dominey and Snyder, 1988); however, studies have not so far documented any such interactions involving crayfish.

\section{ACKNOWLEDGEMENTS}

I am most grateful to Catherine Souty-Grosset for inviting me to present this topic at the Poitiers Conference "European Crayfish, Food, Flagships and Ecosystem Services" in October 2010, and for her constructive suggestions, and to Sylvia Reynolds for her careful reading of the manuscript.

\section{REFERENCES}

Abrahamsson S., 1966. Dynamics of an isolated population of the crayfish Astacus astacus Linné. Oikos, 17, 96-107.

Abrahamsson S. and Goldman C.R., 1970. Distribution, density and production of the crayfish Pacifastacus leniusculus Dana in Lake Tahoe, California-Nevada. Oikos, 21, 83-91.

Adams S.B., 2007. Direct and indirect effects of channel catfish (Ictalurus punctatus) on native crayfishes (Cambaridae) in experimental tanks. Am. Midl. Nat., 158, 85-96.

Alonso F. and Martínez R., 2006. Shelter competition between two invasive crayfish species: a laboratory study. Bull. Fr. Pêche Piscic., 280-281, 1121-1132.

Appelberg M. and Odelström T., 1988. Interaction between European perch (Perca fluviatilis) and juvenile Pacifastacus leniusculus (Dana) in a pond ecosystem. Freshwater Crayfish, 7, 37-45.

Appelberg M., Soderback B. and Odelström T., 1993. Predator detection and perception of predation risk in the crayfish Astacus astacus L. Nord. J. Freshw. Res., 68, 55-62.

Aquiloni L., Brusconi S., Cecchinelli E., Tricarico E., Mazza G., Pagliani A. and Gherardi F., 2010. Biological control of invasive populations of crayfish: the European eel (Anguilla anguilla) as a predator of Procambarus clarkii. Biol. Invasions, 12, 3817-3824.

Barbaresi S. and Gherardi F., 1997. Italian freshwater decapods: exclusion between the crayfish Austropotamobius pallipes (Faxon) and the river crab Potamon fluviatile (Herbst). Bull. Fr. Pêche Piscic., 347, 731-747.

Bishop C., Begley B., Nicholas C., Rader J., Reed E., Sykes K., Williams T., Young E. and Mullen D., 2008. Shelter-use and interactions between banded sculpin (Cottus carolinae) and bigclaw crayfish (Orconectes placidus) in stream-pool habitats. Southeast. Nat., 7, 81-90.

Blake M. and Hart P.J.B., 1993. The behavioural responses of juvenile signal crayfish Pacifastacus leniusculus to stimuli from perch and eels. Freshw. Biol., 29, 89-97.

Blake M.A. and Hart P.J.B., 1995. The vulnerability of juvenile signal crayfish to perch and eel predation. Freshw. Biol., 33, 233-244.

Brown P.J., 2010. Habitat selection and abundance of young-of-year smallmouth bass in north temperate lakes. Trans. Am. Fish. Soc., 139, 1247-1260.

Bubb D.H., O'Malley O.J., Gooderham A.C. and Lucas M.C., 2009. Relative impacts of native and nonnative crayfish on shelter use by an indigenous benthic fish. Aquat. Conserv., 19, 448-455.

Carpenter J., 2005. Competition for food between an introduced crayfish and two fishes endemic to the Colorado River basin. Envir. Biol. Fishes, 72, 335-342.

Crawford L., Yeomans W.E. and Adams C.E., 2006. The impact of introduced signal crayfish Pacifastacus leniusculus on stream invertebrate communities. Aquat. Conserv., 16, 611-621.

Dahl J., 1998. Effects of a herbivorous and a drift-feeding fish on a benthic stream assemblage. Oecologia, 116, 426-432.

Daniels R.A., 1980. Distribution and status of crayfishes in the Pit River drainage, California. Crustaceana, 38, 131-138.

Degerman E., Nilsson P.A., Nyström P., Nilsson E. and Olsson K., 2007. Are fish populations in temperate streams affected by crayfish - A field survey and prospects. Environ. Biol. Fishes, 78, 231-239.

Demers A., Reynolds J.D. and Cioni A., 2004. Habitat preferences of different size classes of Austropotamobius pallipes in an Irish river. Bull. Fr. Pêche Piscic., 370-371, 127-137. 
DiDonato G.T. and Lodge D.M., 1993. Species replacement among Orconectes crayfishes in Wisconsin lakes: the role of predation by fish. Can. J. Fish. Aquat. Sci., 50, 1484-1488.

DiStefano R.J., Litvan M.E. and Horner P.T., 2009. Introduced species: The bait industry as a potential vector for alien crayfish introductions: problem recognition by fisheries agencies and a Missouri evaluation. Fisheries, 34, 586-597.

Dittel A.I. and Epifanio C.E., 2009. Invasion biology of the Chinese mitten crab, Eriocheir sinensis: a brief review. J. Environ. Mar. Biol. Ecol., 374, 79-92.

Dominey W.J. and Snyder A.M., 1988. Kleptoparasitism of freshwater crabs by cichlid fishes endemic to Lake Barombi Mbo, Cameroon, West Africa. Environ. Biol. Fishes, 22, 155-160.

Dorn M.J. and Mittelbach G.G., 1999. More than predator and prey: a review of interactions between fish and crayfish. Vie Milieu, 49, 229-237.

Dorn N.J. and Trexler J.C., 2007. Crayfish assemblage shifts in a large drought-prone wetland: the roles of hydrology and competition. Freshw. Biol., 52, 2399-2411.

Dorn N.J. and Wojdak J.M., 2004. The role of omnivorous crayfish in littoral communities. Oecologia, 140, 150-159.

Edsman L., Füreder L., Gherardi F. and Souty-Grosset C., 2010, Astacus astacus. In: IUCN 2010, IUCN Red List of Threatened Species, Version 2010.3, www.iucnredlist.org.

Elvira B.B., Nicola G.G. and Almodovar A.A., 1996. Pike and red swamp crayfish: a new case on predator-prey relationship between aliens in central Spain. J. Fish Biol., 48, 437-446.

Englund G., 1999. Effects of fish on the local abundance of crayfish in stream pools. Oikos, 87, 48-56.

Everard M., Gray J., Wilkins-Kindemba V. and Cowx I.G., 2009. Impacts of invasive species on ecosystem services: the case of the signal crayfish (Pacifastacus leniusculus). Environ. Law Management, $21,250-259$.

Foster J. and Harper D.M., 2006. The alien Louisiana red swamp crayfish Procambarus clarkii Girard in Lake Naivasha, Kenya, 1999-2003. Freshwater Crayfish, 15, 9-15.

Frütiger A and Müller R., 2002. Controlling unwanted Procambarus clarkii populations by fish predation. Freshwater Crayfish, 13, 309-315.

Füreder L., Gherardi F., Holdich D., Reynolds J., Sibley P. and Souty-Grosset C., 2010. Austropotamobius pallipes. In: IUCN 2010, IUCN Red List of Threatened Species, Version 2010.3, www.iucnredlist.org.

Garvey J.E., Stein R.A. and Thomas H.M., 1994. Assessing how fish predation and interspecific prey competition influence a crayfish assemblage. Ecology, 75, 532-547.

Geiger W., Alcorlo P., Baltanás A. and Montes C., 2005. Impact of an introduced Crustacean on the trophic webs of Mediterranean wetlands. Biol. Invasions., 7, 49-73.

Gherardi F., 2007. Understanding the impact of invasive crayfish. In: Gherardi F. (ed.), Biological invaders in inland waters: profiles, distribution, and threats, Springer, Dordrecht, 507-542.

Gouin N., Grandjean F., Pain S., Souty-Grosset C. and Reynolds J., 2003. Origin and colonization history of the white-clawed crayfish, Austropotamobius pallipes in Ireland. Heredity, 91, 70-77.

Grandjean F., Gouin N., Souty-Grosset C. and Dieguez-Uribeondo J., 2001. Drastic bottlenecks in the endangered crayfish species Austropotamobius pallipes in Spain and implications for its colonization history. Heredity, 86, 431-438.

Grandjean F., Gouin N., Keith P., Noel P., Persat H., Reynolds J., Schulz H., Smietana P. and SoutyGrosset C., 2006. Systematics and phylogeny of freshwater crayfish, with particular reference to historical biogeography of Europe. In: Souty-Grosset C., Holdich D.M., Noel P.Y., Reynolds J.D. and Haffner P. (eds.), Atlas of crayfish in Europe, Muséum national d'Histoire naturelle, Paris, 12-23.

Griffiths S.W., Collen P. and Armstrong J.D., 2004. Competition for shelter among over-wintering signal crayfish and juvenile Atlantic Salmon. J. Fish Biol., 65, 436-447.

Guan R.-Z. and Wiles P.R., 1996. Growth, density and biomass of crayfish, Pacifastacus leniusculus, in a British lowland river. Aquat. Living Resour., 9, 265-272.

Guan R.-Z. and Wiles P.R., 1997. Ecological impact of introduced crayfish on benthic fishes in a British lowland river. Conserv. Biol., 11, 641-647.

Guttiérrez-Yurrita P.J. and Montes C., 1999. Bioenergetics and phenology of the introduced red swamp crayfish, Procambarus clarkii, in Doñana National Park, Spain, and implications for species management. Freshw. Biol., 42, 561-574. 
Haertel-Borer S.S., Zak D., Eckmann R., Baade U. and Hölker F., 2005. Population density of the crayfish Orconectes limosus in relation to fish and macroinvertebrate densities in a small mesotrophic lake - implications for the lake's food web. Int. Rev. Hydrobiol., 90, 523-538.

Harrison M.L., Hoover T.M. and Richardson J.S., 2006. Agonistic behaviours and movement in the signal crayfish, Pacifastacus leniusculus: can dominance interactions influence crayfish size-class distributions in streams? C. J. Zool., 84, 1495-1504.

Hickley P., North E., Muchiri S.M. and Harper D.M., 1994. The diet of largemouth bass, Mixcropterus salmoides, in Lake Naivasha, Kenya. J. Fish Biol., 44, 607-619.

Hirsch P.E. and Fischer P., 2008. Interactions between native juvenile burbot (Lota lota) and the invasive spinycheek crayfish (Orconectes limosus) in a large European lake. Can. J. Fish. Aquat. Sci., 65, 2636-2643.

Hobbs H.H. III, Jass J.P. and Huner J.V., 1989. A review of global crayfish introductions with particular emphasis on two North American species (Decapoda, Cambaridae). Crustaceana, 56, 299-316.

Holdich D.M., 1999. The negative effect of established crayfish introductions. In: Gherardi F. and Holdich D.M. (eds.), Crayfish in Europe as alien species. How to make the best of a bad situation?, A.A. Balkema, Rotterdam, 31-47.

Holdich D.M., Palmer M. and Sibley P.J., 2009a. The indigenous status of Austropotamobius pallipes (Lereboullet) in Britain. In: Brickland J., Holdich D.M. and Imhoff E.M. (eds.), Crayfish Conservation in the British Isles, Proceedings of a conference held in Leeds, 87-94.

Holdich D.M., Reynolds J.D., Souty-Grosset C. and Sibley P.J., 2009b. A review of the ever increasing threat to European crayfish from non-indigenous crayfish species. Knowl. Managt. Aquatic Ecosyst., 394-395, 11.

Hölker F., Dörner H., Schulze T., Haertel-Borer S., Peacor S.D. and Rehner T., 2007. Species-specific response of planktivorous fish to the introduction of a new piscivore: implications for prey fitness. Freshw. Biol., 52, 1793-1806.

Holm J.C., 1989. Atlantic salmon parr (Salmo salar) and noble crayfish (Astacus astacus) in duoculture. Aquac. Eng., 8, 79-94.

Huner J.V. and Avault J.W., 1979. Introductions of Procambarus spp. Freshwater Crayfish, 4, 191-196.

Ilhéu M. and Bernardo J.M., 1995. Trophic ecology of red swamp crayfish Procambarus clarkii (Girard) - preferences and digestibility of plant foods. Freshwater Crayfish, 10, 132-139.

Ilhéu M., Bernardo J.M. and Fernandes S., 2007. Predation of invasive crayfish on aquatic invertebrates: the effect of Procambarus clarkii on fish assemblages in Mediterranean temporary streams. In: Gherardi F. (ed.), Biological invaders in Inland waters, Springer, 734 p.

IUCN, 2010. Red list of threatened crustaceans, www.iucnredlist.org/documents/summarystatistics/ 2010/.

Jones J.P.G., 2007. The ecology and conservation status of Madagascar's endemic freshwater crayfish (Parastacidae: Astacoides). Freshw. Biol., 52, 1820-1833.

Keller T.A. and Moore P.A., 2000. Context-specific behavior: crayfish size influences crayfish-fish interactions. J. North Am. Benthol. Soc., 19, 344-351.

Kennedy M. and Fitzmaurice P., 1971. Growth and food of brown trout Salmo trutta (L.) in Irish waters. Proc. R. Ir. Acad. B, 71, 269-352.

Kirk D.J. and Smock L.A., 2000. Interspecific and intraspecific interactions between crayfish (Cambarus longulus) and hellgrammites (Corydalus cornutus) and the influence of a predatory fish (Micropterus dolomieu). Am. Midl. Nat., 144, 317-327.

Kozák P., Buric M. and Policar T., 2006. The fecundity, time of egg development and juveniles production in spiny-cheek crayfish (Orconectes limosus) under controlled conditions. Bull. Fr. Pêche Piscic., 180-181, 1171-1182.

Kuhlmann M.L., Badylak S.M. and Carvin E.L., 2008. Testing the differential predation hypothesis for the invasion of rusty crayfish in a stream community: Laboratory and field experiments. Freshw. Biol. 53, 113-128.

Larsen E.R., Busack C.A., Anderson J.D. and Olsen J.D., 2010. Widespread distribution of the nonnative northern crayfish (Orconectes virilis) in the Columbia River Basin. Northwest Sci., 84, $108-111$.

Lewis W.M. and Helms D.R., 1964. Vulnerability of forage organisms to largemouth bass. Trans. Am. Fish. Soc., 93, 315-318. 
Light T., 2005. Behavioral effects of invaders: alien crayfish and native sculpin in a California stream. Biol. Invasions, 7, 3353-3367.

Lodge D.M. and Lorman J.G., 1987. Reductions in submersed macrophyte biomass and species richness by the crayfish Orconectes rusticus. Can. J. Fish. Aquat. Sci., 44, 591-597.

Lorman J.G. and Magnuson J.J., 1978. The role of crayfishes in aquatic systems. Fisheries, 3, 8-10.

Lowery R.S. and Mendes A.J., 1977. Procambarus clarkii in Lake Naivasha, Kenya, and its effects on established and potential fisheries. Aquaculture, 11, 111-121.

Lucey J. and McGarrigle M.L., 1987. The distribution of the crayfish Austropotamobius pallipes (Lereboullet) in Ireland. Ir. Fish. Investigations A, 29, 1-13.

Mather M.E. and Stein R.A.S., 1993. Direct and indirect effects of fish predation on the replacement of a native crayfish by an invading congener. Can. J. Fish. Aquat. Sci., 50, 1279-1288.

Matsuzaki S.M., Usio N., Takamura N. and Washitani J., 2009. Contrasting impacts of invasive engineers on freshwater ecosystems; an experiment and meta-analysis. Oecologia, 158, 673-686.

Matthews M.A. and Reynolds J.D., 1992. Ecological impact of crayfish plague in Ireland. Hydrobiologia, 234, 1-6.

Matthews M., Reynolds J.D. and Keatinge M.J., 1993. Macrophyte reduction and benthic community alteration by the crayfish Austropotamobius pallipes (Lereboullet). Freshwater Crayfish, 9, 289-299.

McCarthy J.M., Hein C.L., Olden J.D. and Vander Zanden M.J., 2006. Coupling long-term studies with meta-analysis to investigate impacts of non-native crayfish on zoobenthic communities. Freshw. Biol., 51, 224-235.

McNeely D.L., Futrell B.N. and Sih A., 1990. An experimental study on the effects of crayfish on the predator-prey interaction between bass and sculpin. Oecologia, 85, 69-73.

Miller J.E., Savino J.F. and Neely R.K., 1992. Competition for food between crayfish (Orconectes virilis) and the Slimy Sculpin (Cottus cognatus). J. Freshw. Ecol., 7, 127-136.

Momot W.T., Gowing H. and Jones P.D., 1978. The dynamics of crayfish and their role in ecosystems. Am. Midl. Nat., 99, 10-35.

Morgan D.L., Gill H.S., Maddern M.G. and Beatty S.J., 2004. Distribution and impacts of introduced freshwater fishes in Western Australia. N. Z. J. Mar. Freshw. Res., 38, 511-523.

Moriarty C., 1963. Food of perch (Perca fluviatilis, L.) and trout (Salmo trutta, L.) in an Irish reservoir. Proc. R. Ir. Acad. B, 63, 1-31.

Moriarty C., 1973. A study of Austropotamobius pallipes in Ireland. Freshwater Crayfish, 1, 57-68.

Moriarty C., 1974. Studies of the eel Anguilla Anguilla L. in Ireland. 3. In the Shannon Catchment. Ir. Fish. Investigations $A, 14,1-25$.

Moriarty C., 1983. Age determination and growth rate of eels, Anguilla anguilla (L.). J. Fish. Biol., 23, 257-264.

Neveu A., 2001a. Les poissons carnassiers locaux peuvent-ils contenir l'expansion des écrevisses étrangères introduites ? Efficacité de trois espèces de poissons face à deux espèces d'écrevisses dans des conditions expérimentales. Bull. Fr. Pêche Piscic., 361, 683-704.

Neveu A., 2001b. Confrontation expérimentale entre des poissons omnivores autochtones (11 espèces) et des écrevisses étrangères introduites (2 espèces). Bull. Fr. Pêche Piscic., 361, 705-735.

Nyström P., 2001. Ecology. In: Holdich D.M. (ed.,) Biology of Freshwater Crayfish, Blackwell Science, 192-235.

Nyström P. and Strand A., 1995. Grazing by a native and an exotic crayfish on aquatic macrophytes. Freshw. Biol., 36, 673-682.

Olden J.D., 2006. Biotic homogenization: a new research agenda for conservation biogeography. J. Biogeog., 33, 2027-2039.

Olden J.D., Kennard M.J. and Pusey B.J., 2008. Species invasions and the changing biogeography of Australian freshwater fishes. Glob. Ecol. Biogeog., 17, 25-37.

Olsson K., Stenroth P., Nystrom P., Holmqvist N., Mclntosh A.R. and Winterbourn M.J., 2006. Does natural acidity mediate interactions between introduced brown trout, native fish, crayfish and other invertebrates in West Coast New Zealand streams? Biol. Conserv., 132, 255-267.

Paaver T. and Hurt M., 2009. Status and management of noble crayfish Astacus astacus in Estonia. Knowl. Managt. Aquatic Ecosyst., 394-395, 18. 
Peay S., Guthrie N., Spees J., Nilsson E. and Bradley P., 2009. The impact of signal crayfish (Pacifastacus leniusculus) on the recruitment of salmonid fish in a headwater stream in Yorkshire, England. Knowl. Managt. Aquatic Ecosyst., 394-395, 12.

Poole W.R. and Reynolds J.D., 1996. Growth rate and age at migration of Anguilla anguilla. J. Fish Biol., 48, 633-642.

Proman J. and Reynolds J.D., 2000. Differences in head shape of the European eel, Anguilla anguilla (L.). Fish. Manage. Ecol., 7, 349-354.

Pyke G.H., 1984. Optimal foraging theory: a critical review. Ann. Rev. Ecol. Syst., 15, 523-575.

Raat A.J.P., 1988. Synopssis of biological data on the Northern Pike, Esox lucius Linnaeus, 1758, FAO, Rome, $178 \mathrm{p}$.

Rahel F.J. and Stein R.A., 1988. Complex predator-prey interactions and predator intimidation among crayfish, piscivorous fish, and small benthic fish. Oecologia, 75, 94-98.

Ramalho R. and Anastacio P., 2011. Interactions between fish and crayfish: prey switching. In: European Crayfish: food, flagships and ecosystem services, 26-29 October 2010, Poitiers, France.

Rankin E.T., 1986. Habitat selection by smallmouth bass in response to physical characteristics in a natural stream. Trans. Am. Fish. Soc., 115, 322-334.

Reynolds J.D., 1979. Crayfish ecology in Ireland. Freshwater Crayfish, 4, 215-220.

Reynolds J.D., 2008. Man-handled? How and when did freshwater invertebrates cross the sea to Ireland? A review with particular reference to crustaceans. In: Davenport J.L., Sleeman D.P. and Woodman P.C. (eds.), Mind the gap: Postglacial Colonization of Ireland 2006, Ir. Naturalists' J., Special Supplement 2008, 83-95.

Reynolds J.D. and O'Keeffe C., 2005. Dietary patterns in stream- and lake-dwelling populations of Austropotamobius pallipes. Bull. Fr. Pêche Piscic., 376-377, 715-730.

Reynolds J.D. and Souty-Grosset C., 2011. Management of freshwater biodiversity: crayfish as bioindicators, Cambridge University Press (in press).

Rubin J. and Svensson M., 1993. Predation by the noble crayfish Astacus astacus (L), on emerging fry of sea trout, Salmo trutta (L). Nordic J. Freshw. Res., 68, 100-104.

Rudnick D.A., Hieb K., Grimmer K.F. and Resh V.H., 2003. Patterns and processes of biological invasions: the Chinese mitten crab in San Francisco Bay. Basic Appl. Ecol., 4, 249-262.

Savino J.F. and Miller J.E., 1991. Crayfish (Orconectes virilis) feeding on young lake trout (Salvelinus namaycush): effect of rock size. J. Freshw. Ecol., 6, 161-170.

Shave C.R., Townsend C.R. and Crowl T.A., 1994. Anti-predatory behaviours of a freshwater crayfish (Paranephrops zealandicus) to a native and introduced predator. N. Z. J. Ecol., 18, 1-10.

Simon K.S. and Townsend C.R., 2003. Impacts of freshwater invaders at different levels of ecological organization, with emphasis on salmonids and ecosystem consequences. Freshw. Biol., 48, 982-994.

Söderbäck B., 1994. Interactions among juveniles of two freshwater crayfish species and a predatory fish. Oecologia, 100, 229-235.

Soto D., Arismendi I., González J., Sanzana J., Jara F., Jara C., Guzman E. and Lara A., 2006. Southern Chile, trout and salmon country: invasion patterns and threats for native species. Rev. Chil. Hist. Nat., 79, 97-117.

Souty-Grosset C., Holdich D.M., Noël P.Y., Reynolds J.D. and Haffner P., 2006. Atlas of crayfish in Europe, Muséum national d'Histoire naturelle, Paris, Patrimoines Naturels, 64, 187 p.

Stancliffe-Vaughan A., 2009. Non-native crayfish - a community research and trapping initiative on the River Lark, Suffolk. Crayfish News: IAA Newsletter, 31, 5-7.

Stein R.A., 1977. Selective predation, optimal foraging in the predator-prey interaction between fish and crayfish. Ecology, 58, 1237-1253.

Stein R.A. and Magnuson J.J., 1976. Behavioral response of crayfish to a fish predator. Ecology, 57, 751-761.

Stenroth P. and Nyström P., 2003. Exotic crayfish in a brown water stream: effects on juvenile trout, invertebrates and algae. Freshw. Biol., 48, 466-475.

Svärdson G., 1972. The predatory impact of the eel (Anguilla anguilla L.) on populations of crayfish (Astacus astacus L.). Rep. Inst. Freshw. Drottingholm, 52, 149-191. 
Swecker C.D., Jones T.G., Donahue K. II, McKinney D. and Smith G.D., 2010. The extirpation of Orconectes limosus (spinycheek crayfish) populations in West Virginia. Southeast. Nat., 9, $155-164$.

Taub S.H., 1972. Exploitation of crayfish by largemouth bass in a small Ohio pond. Prog. Fish-Cult., 34, 55-58.

Usio N. and Townsend C.W., 2000. Diet of the New Zealand crayfish Paranephrops zealandicus in relation to stream physiochemistry, predatory fish and invertebrate prey. N. Z. J. Mar. Freshw. Sci., 34, 557-567.

Veldhuizen T.C. and Stanish S., 1999. Overview of the life history, distribution, abundance, and impacts of the Chinese mitten crab, Eriocheir sinensis, California Department of Water Resources, Environmental Services Office, Sacramento, $21 \mathrm{p}$.

Wangpen P., 2007. The role of shelter in Australian freshwater crayfish (Cherax spp.) polysystems. Crayfish News, 29, 4-5.

Went A.E.J., 1971. The distribution of Irish char, Salvelinus alpinus. Ir. Fish. Investigations, 6, 5-11.

Werner E.E. and Hall D.J., 1988. Ontogenic habitat shifts in bluegill: the foraging rate - predation risk trade-off. Ecology, 69, 1352-1366.

Westman K., 1991. The crayfish fishery in Finland - its past, present and future. Finn. Fish. Res., 12, 187-216.

Whitmore N., Huryn A.D., Arbuckle C.J. and Jansma F., 2000. Ecology and distribution of the freshwater crayfish Paranephrops zealandicus, Otago Dept. of Conservation, Science for Conservation, 138, Wellington, NZ, $42 \mathrm{p}$. 